\title{
A RENAL LESION IN ASSOCIATION WITH INFLUENZA
}

\author{
BY \\ I. P. BESWICK AND R. FINLAYSON \\ From the Department of Morbid Anatomy, Royal Free Hospital School of Medicine, London
}

(RECEIVED FOR PUBLICATION DECEMBER 19, 1958)

Between the beginning of October, 1957, and the end of January, 1958, seven cases of influenza came to necropsy at the Royal Free Hospital.

All these patients had influenzal tracheitis, bronchitis, and bronchopneumonia, and six of them, died from this cause. Influenza virus $A$ (Asian strain) was isolated from the lungs of all six. In two cases the virus was the only pathogen, but in the other four there was also a secondary bacterial invader; three patients' lungs yielded Staph. pyogenes and the other Klebsiella pneumoniae. From the lungs of the seventh patient no virus was grown, but this young woman died during a relapse of the influenza. She had suppurative pericarditis and suppurative bronchopneumonia with lung abscess in addition to the influenzal lesions of the respiratory tract; from all the suppurative lesions Strep. pyogenes was isolated.

The clinical features, urinary findings, treatment, and post-mortem appearances are summarized in the accompanying table. It is noteworthy that the longest interval between the onset of influenza and death was 11 days, and, in view of the renal lesions to be described, it is of interest that in each case there was a terminal phase, lasting one to three days, characterized by severe toxaemia and peripheral circulatory failure.

\section{Morbid Anatomy and Histology}

The kidneys from all cases showed varying degrees of cortical pallor. In three cases the renal papillae attracted attention at necropsy because they were conspicuously swollen and were bright red ; in the other four no gross pyramidal changes were observed. Similar microscopic changes were, however, found in the kidneys of all seven patients, though they varied in degree and extent. The pelves and ureters appeared normal. Histologically varying degrees of interstitial oedema and congestion were always present in the medullae and were most marked in the papillae. As would be expected, both these changes were most noticeable microscopically in the cases in which macroscopic alteration in the papillae was visible. The vascular congestion was often patchy in distribution; where it was most intense the appearances suggested that actual stasis of the blood in the capillaries had occurred during life. In one case (Case 2) there was a very striking accumulation of primitive leucocytes in vessels throughout the medulla, and especially in the papillae; this feature was detectable in the other cases but in them was slight only.

The papillae were denuded of their covering transitional epithelium; this desquamation could often be seen to cease abruptly at the bases of the papillae.

Tubular lesions were found in the medullae; they principally involved the collecting tubules, but also, to a less severe degree, the loops of Henle. Many collecting tubules had shed their lining epithelium completely, the basement membranes being left bare. It was, of course, difficult to exclude post-mortem autolysis as the cause of the tubular desquamation and it doubtless was the cause of some of it. However, close inspection of the tubules where there were some remains of epithelium still adherent or partly adherent to the basement membrane revealed changes in these cells which suggested they had undergone ante-mortem degeneration and necrosis. Many of the nuclei were pyknotic and the cytoplasm often showed a pale purple granularity which was succeeded by cytoplasmic disintegration. Epithelial cells of this kind could sometimes be seen falling away from the basement membranes and adding themselves to casts composed of similar granular material lying in the tubular lumina (Figs. 1 and 2). In other areas, tubules with intact epithelial linings contained similar casts. Several tubules which showed the epithelial changes just described also showed swelling of the basement membranes. Tubular ruptures and tubulo-venous anastomoses could not be demonstrated with certainty, but red cells could often be seen in the lumina of tubules which showed the necrotic lesions considered to be ante mortem. In places small groups of collecting 
TABLE

CLINICAL AND POST-MORTEM SUMMARIES OF SEVEN CASES OF INFLUENZA

\begin{tabular}{|c|c|c|c|c|c|c|c|c|}
\hline \multirow{3}{*}{$\begin{array}{l}\text { Case } \\
\text { No. } \\
1\end{array}$} & \multirow{3}{*}{ Sex } & \multirow{3}{*}{ Age } & \multirow{2}{*}{\multicolumn{2}{|c|}{$\begin{array}{l}\text { Duration } \\
\text { of } \\
\text { Influenza }\end{array}$}} & \multirow{3}{*}{ Clinical Summary } & \multirow{3}{*}{$\begin{array}{l}\quad \text { Treatment } \\
\text { Penicillin } \\
\text { Sulphatriad } \\
\text { Chloromycetin } \\
\text { Erythromycin } \\
\text { Noradrenaline } \\
\text { Hydrocortisone } \\
\text { Oxygen }\end{array}$} & \multicolumn{2}{|c|}{ Post-mortem Findings } \\
\hline & & & & & & & Morbid Anatomy & $\begin{array}{c}\text { Bacteriology and } \\
\text { Virology of } \\
\text { Respiratory System }\end{array}$ \\
\hline & & & & days & & & $\begin{array}{l}\text { Necropsy } 17 \text { hr. after death. } \\
\text { Typical influenzal tracheitis, } \\
\text { bronchitis, and bilateral bron- } \\
\text { chopneumonia } \\
\text { Kidneys: cortices pale and } \\
\text { slightly swollen. Medullae } \\
\text { congested }\end{array}$ & $\begin{array}{l}\text { 1. Influenza virus } \\
\text { (Asian strain) } \\
\text { 2. Staph. pyogenes }\end{array}$ \\
\hline 2 & $\mathbf{F}$ & 23 & 8 & , & $\begin{array}{l}\text { Sixteen weeks pregnant. Mild } \\
\text { attack of influenza at onset. Two } \\
\text { days before death considered to } \\
\text { be convalescent. Then suddenly } \\
\text { developed cough, high fever, and } \\
\text { pain in back and across front of } \\
\text { chest. Cardiac impulse not pal- } \\
\text { pable; heart sounds soft and } \\
\text { distant. Signs of bilateral } \\
\text { bronchopneumonia. No res- } \\
\text { ponse to treatment } \\
\text { Urine: trace of albumin; occa- } \\
\text { sional white and red blood cells; } \\
\text { a few granular casts. No } \\
\text { organisms } \\
\text { Culture: sterile }\end{array}$ & $\begin{array}{l}\text { Chloromycetin } \\
\text { Hydrocortisone } \\
\text { Gamma globulin } \\
\text { Noradrenaline } \\
\text { Fresh blood } \\
\quad \text { transfusion } \\
\text { Oxygen }\end{array}$ & $\begin{array}{l}\text { Necropsy } 18 \text { hr. after death. } \\
\text { Trachea and bronchi denuded } \\
\text { of epithelium and bright red. } \\
\text { Lungs showed haemorrhagic } \\
\text { influenzal pneumonia; small } \\
\text { acute abscess in right upper } \\
\text { lobe } \\
\text { Heart: acute suppurative peri- } \\
\text { carditis; myocardium clay- } \\
\text { coloured, small abscesses in } \\
\text { wall of left ventricle } \\
\text { Kidneys: renal papillae bright } \\
\text { red and very swollen. Cortices } \\
\text { pale and slightly swollen }\end{array}$ & $\begin{array}{l}\text { 1. Influenza virus not } \\
\text { isolated } \\
\text { 2. Strep. pyogenes } \\
\text { (Strep. pyogenes } \\
\text { also isolated } \\
\text { from pericardial } \\
\text { exudate) }\end{array}$ \\
\hline 3 & $\mathbf{F}$ & 19 & 8 & , & $\begin{array}{l}\text { Mild attack of influenza at onset. } \\
\text { Considered to be recovering } 3 \\
\text { days before death; thereafter } \\
\text { she rapidly developed high fever } \\
\text { and signs of encephalitis and } \\
\text { bilateral bronchopneumonia. } \\
\text { Lapsed into coma. No response } \\
\text { to treatment } \\
\text { Urine: no abnormal findings }\end{array}$ & $\begin{array}{l}\text { Chloromycetin } \\
\text { Cortisone } \\
\text { Anti-staphylo- } \\
\text { coccal serum } \\
\text { Prednisone } \\
\text { Oxygen }\end{array}$ & $\begin{array}{l}\text { Necropsy } 18 \text { hr. after death. } \\
\text { Typical influenzal tracheitis, } \\
\text { bronchitis, and bilateral bron- } \\
\text { chopneumonia } \\
\text { Kidneys: papillae deep red and } \\
\text { very swollen. Cortices pale } \\
\text { and slightly swollen }\end{array}$ & $\begin{array}{l}\text { 1. Influenza virus } \mathbf{A} \\
\text { (Asian strain) } \\
\text { 2. No bacterial patho- } \\
\text { gens isolated }\end{array}$ \\
\hline 4 & $\mathbf{M}$ & 66 & 4 & , & $\begin{array}{l}\text { Fairly mild attack at onset, with } \\
\text { general malaise, headache, vom- } \\
\text { iting, and slight diarrhoea. } 2 \\
\text { days before death developed } \\
\text { severe cough, diarrhoea, bilateral } \\
\text { bronchopneumonia and extreme } \\
\text { collapse } \\
\text { No response to treatment } \\
\text { Urine: none obtained }\end{array}$ & $\begin{array}{l}\text { Penicillin } \\
\text { Oxygen }\end{array}$ & $\begin{array}{l}\text { Necropsy } 56 \text { hr. after death. } \\
\text { Mild, pre-existing chronic } \\
\text { bronchitis and emphysema. } \\
\text { Severe acute purulent trachei- } \\
\text { tis and bronchitis. Haemor- } \\
\text { rhagic influenzal broncho- } \\
\text { pneumonia with suppuration } \\
\text { in the lower lobes } \\
\text { Kidneys: Capsules stripped } \\
\text { with slight difficulty. Cor- } \\
\text { tices pale and swollen }\end{array}$ & $\begin{array}{l}\text { 1. Influenza virus } \\
\text { (Asian strain) } \\
\text { 2. Klebsiella } \\
\text { pneumoniae }\end{array}$ \\
\hline 5 & $\mathbf{M}$ & 21 & 2 & , & $\begin{array}{l}\text { Mild onset of influenza with cold } \\
\text { and sore throat. Severe cough- } \\
\text { ing and vomiting that night. } \\
\text { Found collapsed next day and } \\
\text { removed to hospital. Signs of } \\
\text { bronchopneumonia and peri- } \\
\text { pheral circulatory collapse. No } \\
\text { urine obtained. No response to } \\
\text { treatment }\end{array}$ & $\begin{array}{l}\text { Penicillin } \\
\text { Coramine } \\
\text { Oxygen }\end{array}$ & $\begin{array}{l}\text { Necropsy } 8 \text { hr. after death. } \\
\text { Typical influenzal tracheitis, } \\
\text { bronchitis, and bilateral bron- } \\
\text { chopneumonia } \\
\text { Kidneys: Medullae congested, } \\
\text { increased pallor of cortices }\end{array}$ & $\begin{array}{l}\text { 1. Influenza virus } A \\
\text { (Asian strain) } \\
\text { 2. Staph. pyogenes }\end{array}$ \\
\hline 6 & $\mathbf{M}$ & 69 & 3 & , & $\begin{array}{l}\text { Mild onset of influenza; at work } \\
\text { for first two days of illness. } \\
\text { Then severe diarrhoea devel- } \\
\text { oped, followed by high fever, } \\
\text { bronchopneumonia, and peri- } \\
\text { pheral circulatory failure } \\
\text { No response to treatment. No } \\
\text { urine obtained for examination }\end{array}$ & $\begin{array}{l}\text { Oxygen (died } \\
\text { before any } \\
\text { other treat- } \\
\text { ment could be } \\
\text { given) }\end{array}$ & $\begin{array}{l}\text { Necropsy } 19 \text { hr. after death. } \\
\text { Typical influenzal tracheitis, } \\
\text { bronchitis, and bilateral bron- } \\
\text { chopneumonia } \\
\text { Kidneys: Renal papillae deep } \\
\text { red and very swollen. Cor- } \\
\text { tices rather pale }\end{array}$ & $\begin{array}{l}\text { 1. Influenza virus } \\
\text { (Asian strain) } \\
\text { 2. Staph. pyogenes }\end{array}$ \\
\hline 7 & $\mathbf{M}$ & 60 & & , & $\begin{array}{l}\text { History of chronic bronchitis, with } \\
\text { recent attack of pneumonia. } \\
\text { Influenza mild until } 24 \mathrm{hr} \text {. before } \\
\text { death, when high fever, signs of } \\
\text { bronchopneumonia, and peri- } \\
\text { pheral circulatory failure devel- } \\
\text { oped. No response to treatment. } \\
\text { Urine normal at onset of influenza. } \\
\text { Not examined later }\end{array}$ & $\begin{array}{l}\text { Penicillin } \\
\text { Achromycin } \\
\text { Aminophylline } \\
\text { A.C.T.H. } \\
\text { Oxygen }\end{array}$ & $\begin{array}{l}\text { Necropsy } 36 \text { hr. after death. } \\
\text { Chronic bronchitis and severe } \\
\text { hypertrophic pulmonary em- } \\
\text { physema. Typical influenzal } \\
\text { tracheitis, bronchitis, and } \\
\text { bronchopneumonia } \\
\text { Kidneys: Uniformly congested }\end{array}$ & $\begin{array}{l}\text { 1. Infiuenza virus } A \\
\text { (Asian strain) } \\
\text { 2. No bacterial patho- } \\
\text { gens isolated }\end{array}$ \\
\hline
\end{tabular}




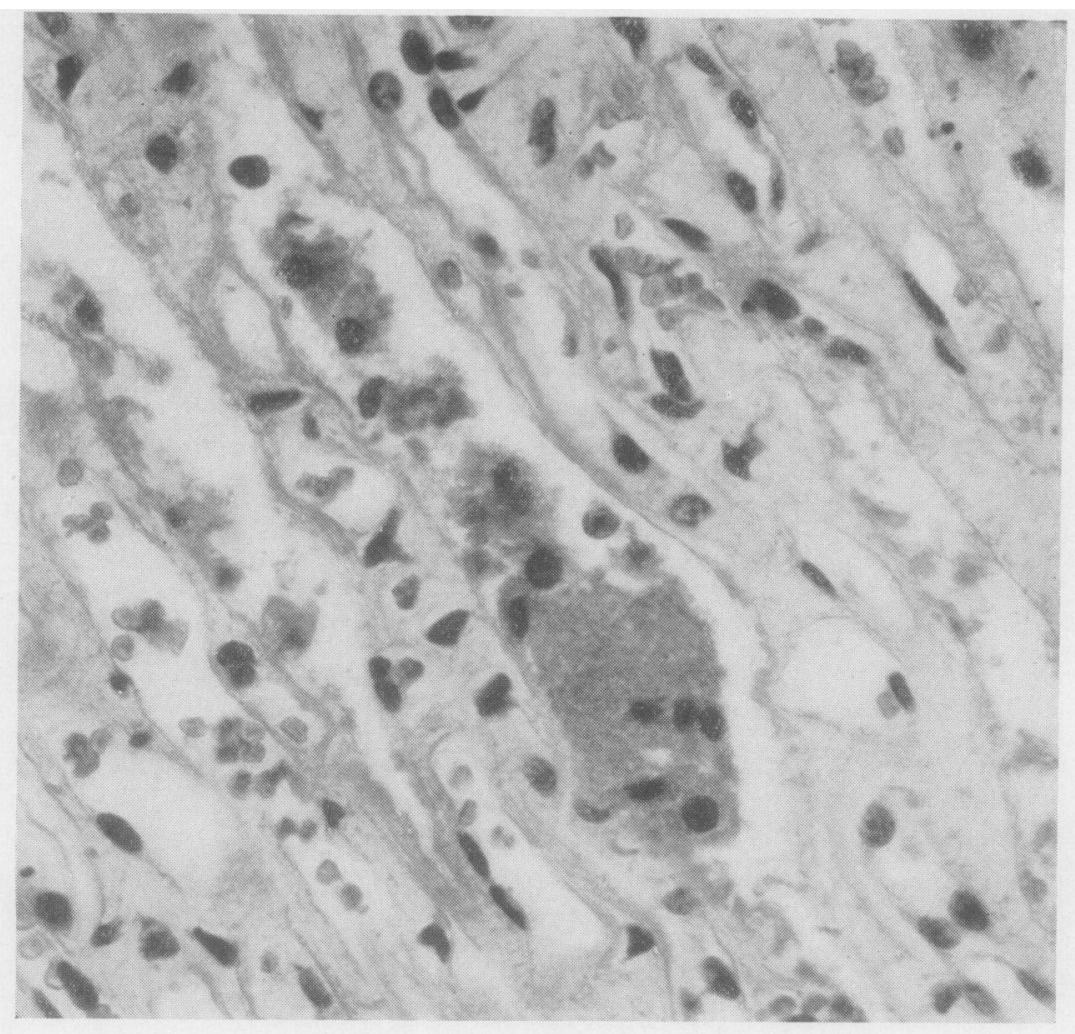

Figs. 1 and 2.-Collecting tubules in renal medullae showing progressive cell necrosis and disintegration of purplish, granular cytoplasm of the epithelium with formation of casts of similar material within the tubular lumina. Haematoxylin and eosin, $\times 540$.

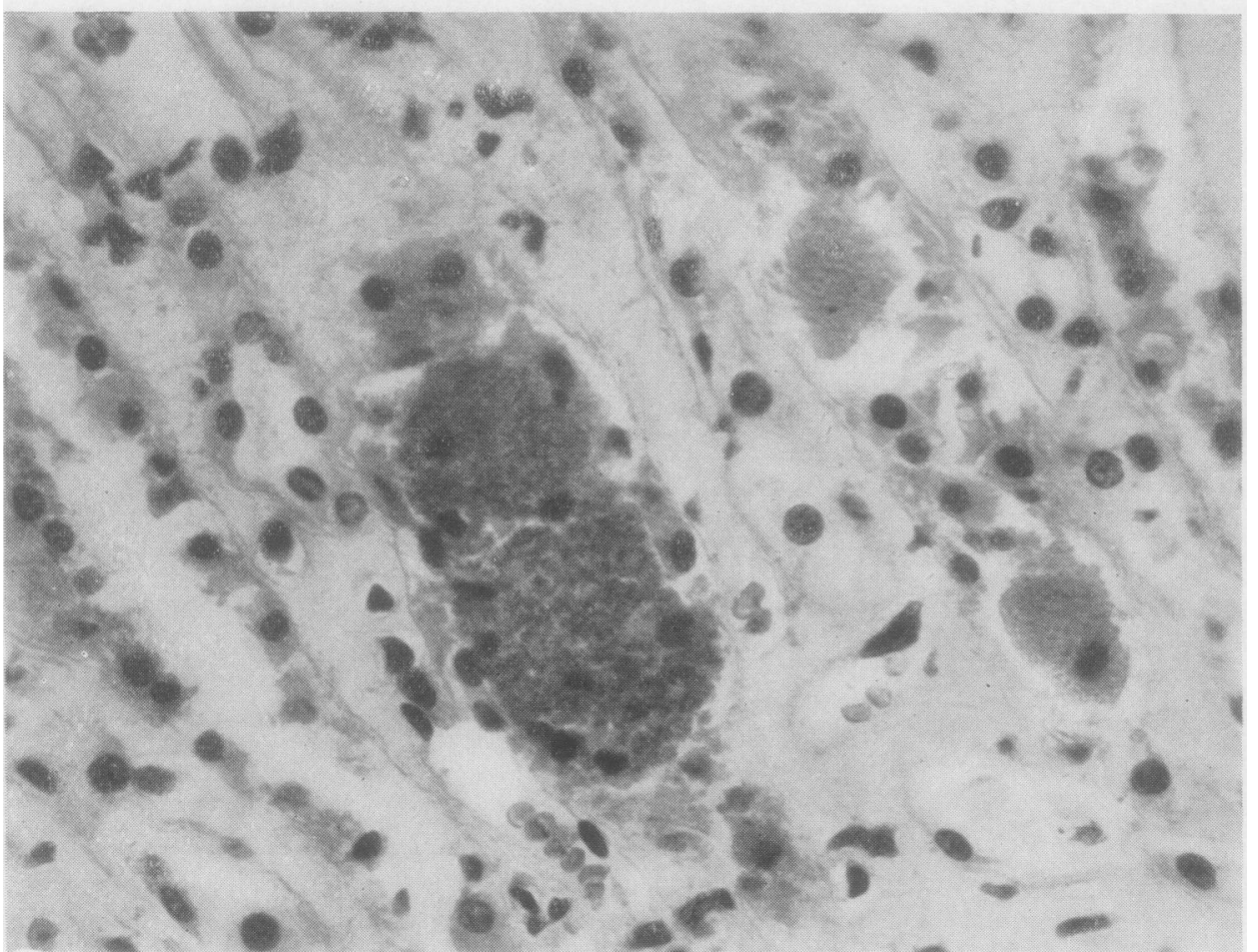


tubules attracted attention under the low power of the microscope because they were filled with loosely-arranged masses of pleomorphic epithelial cells. High-power examination showed some of the cells to have pyknotic nuclei and granular, disintegrating cytoplasm; others were angular in shape, had large hyperchromatic nuclei, and appeared to be regenerating. Mitotic figures in the regenerating cells were very scanty, but a fair number of binucleate cells were seen.

Tubules showing the appearances just described were numerous in only three cases, though lesser degrees of similar changes could be seen in the collecting tubules in all cases. At this point it may be well to remark that many tubules were present in all the kidneys in this series in which separation of the epithelium into the lumina was considered to be the result of fixation and postmortem artefacts only; these included all tubules in which the lining epithelium had separated en masse, forming coherent epithelial rings inside tubules, and all tubules in which small rows of desquamated cells adhered together in groups of two, three, four, or more cells. Tubules affected in this way by autolysis differed greatly in appearance from those described above, in which the lumina contained a mixture of degenerating and regenerating epithelial cells.

Milder tubular lesions were observed in the loops of Henle in all cases; frank necrosis was absent, but in places the lining cells had swollen and also showed increased cytoplasmic eosinophilia. The loops of Henle contained many hyaline eosinophil casts.

In four of the seven cases there were varying amounts of calcium deposited in the renal tubules (Cases 3, 5, 6, and 7). Two of these patients were elderly, but the other two were young individuals. Calcium deposition was confined to degenerate epithelium in the medullae in three instances, but in the fourth patient, a man aged 60 years, there was some calcification of the epithelium of the cortical tubules. Post-mortem autolysis was advanced in the renal cortices in this case and appeared to be uniform throughout the cortical tubules which showed no evidence of focal or diffuse necrosis.

No ante-mortem lesions more severe than cloudy swelling were detected in the cortical tubules of any patient in the series. The capsular spaces of the Malpighian corpuscles were somewhat dilated and contained small amounts of protein. The glomeruli were essentially normal in all cases, except for the presence of a few sclerosed glomeruli in very occasional pyelo- nephritic scars in the cortices of the older individuals. Apart from this, none of the kidneys in the series showed any evidence of chronic renal disease and there were no significant hypertensive changes.

\section{Discussion}

Renal lesions in association with influenza have occasioned little detailed comment in the medical literature. Winternitz, Wason, and McNamara (1920) in their classic work on the pathology of this infection stated that cloudy swelling of the parenchymatous organs was marked and in many cases was associated with cellular necrosis in the liver and kidneys; the necrosis was usually focal. Mitotic figures in the cells of the convoluted tubules, possibly indicating previous damage, were occasionally seen. Acute nephritis, previously reported, was not seen in this large series of cases.

Opie (1928), in a review of the pathology of influenza, stated that parenchymatous degeneration of kidney tubules was often conspicuous, but details of the site of the tubular lesions were not recorded. Earlier, Symonds (1918) reported a series of 22 cases of influenza, 11 of them fatal, in young soldiers; well-marked signs of renal disease complicated the respiratory infection. Urine examination revealed abundant albuminuria and numerous casts, but gross haematuria was not a feature and small numbers of red cells were found in only three of the cases. At necropsy none of the kidneys showed any changes except some increased adherence of the capsules; histological examination revealed congestion and varying degrees of tubular degeneration, but autolysis was too advanced to permit any detailed studies of the tubular lesions. In our series of seven cases the urinary findings are poorly documented and it has not been possible to correlate them with the renal pathology. Several of the patients, however, were admitted in extremis and produced little or no urine; those in hospital passed suddenly into a short terminal phase and again no urine was obtained.

Lucke, Wight, and Kime (1919) reviewed the pathology and bacteriology of 126 fatal cases of influenza and discussed the renal findings in considerable detail. Ninety per cent. of the kidneys examined were somewhat enlarged, the cut surfaces were moist and bloody, the cortices were usually swollen. "In every instance parenchymatous changes, usually of mild degree, but often quite severe were observed." The histological findings included moderate oedema of the interstitial tissue, swelling of the capsular epithelium, and deposition 
of granular eosinophil material in capsular spaces and tubular lumina. The tubular epithelium was swollen, ragged in outline and often vacuolated; nuclear changes ranged from poor staining to complete disappearance. These authors remarked that tubular damage was seldom uniformly distributed, groups of necrotic tubules being seen in close proximity to normal ones. They found that "in every case the convoluted tubules were more affected than the straight tubules," and here their observations differ from the findings in the present series of cases. Nuzum, Pilot, Stangl, and Bonar (1918), Blanton and Irons (1918), Symmers (1918), Dever, Boles, and Case (1919), Plenge (1952), and Fischer (1957), though dealing in much less detail with renal lesions in influenza than did Lucke et al. (1919), agreed with the latter authors as to their nature and distribution.

In publications stemming from the recent influenzal pandemic little has been written about renal lesions. A combined study group (Brit. med. $J ., 1958)$, reviewing some aspects of the recent epidemic of influenza in Dundee, record pathological observations on 24 necropsies and state that "a feature of nine cases was extreme pallor of the kidneys." In three of these cases there was microscopical evidence of bilateral necrosis of proximal tubules, but in the remaining six cases only cloudy swelling and post-mortem autolysis was found. Neilson (1958), reporting three sudden deaths from fulminating influenza, found intense congestion of the kidneys. Roberts (1957) records that "no significant change was found in any of the viscera apart from the respiratory system " in nine fatal cases of influenza in previously healthy individuals. Giles and Shuttleworth (1957), reviewing the post-mortem findings in 46 influenzal deaths, found longstanding, chronic renal disease in four patients. One young girl was admitted to hospital with influenza and pre-eclamptic toxaemia of pregnancy; she developed pneumonia and died in the first stage of labour two days later, and the kidneys showed oedema and relative avascularity of the glomeruli. Darke, Watkins, and Whitehead (1957) in their fatal case of influenzal pneumonia found only toxic changes in the liver in addition to the respiratory lesions. Herrmann, Ogura, Johnson, Toll, and White (1958), in a detailed review of 23 cases of sudden death reported to the Denver coroner in October, 1957, and diagnosed at necropsy as being caused by influenza, mention briefly that they consistently observed " mild degenerative changes in such organs as the heart and kidneys."
The particular interest of our material is that the renal lesions were largely concentrated in the medullae. Some of the histological changes observed were undoubtedly autolytic, and others, such as minor degrees of tubular calcification, almost certainly antedated the final illness, but it is difficult to account for all the changes observed on these grounds. Our cases all showed uniform cloudy swelling without necrosis in the epithelium of Bowman's capsule and the proximal tubules; this is in accordance with the experience of previous authors. It seems probable that attention was then drawn to the focal lesions in the lower tubules by the striking changes in the papillae which could be seen on macroscopic examinations of the kidneys from some of the cases.

In the light of the evidence at present available to us, we do not consider it justifiable firmly to ascribe the distal tubular damage to influenza in itself. Unfortunately, renal tissue for virological studies was not taken at necropsy, and viral inclusions are not demonstrable in tissues infected by influenza. The use of embryonic human and adult monkey kidney tissue viruses (Mogabgab, Green, and Dierkhising, 1954 ; Mogabgab, Green, Dierkhising, and Phillips, 1955) does, however, suggest that these organisms may have some affinity for renal epithelium.

It is improbable that the renal lesions were due to direct bacterial infections, because no organisms were identified in histological preparations and the morphological changes were not those of acute bacterial inflammation. Moreover, two of the cases had no secondary bacterial invasion of the respiratory tract.

The very diversity of medical treatment makes it unlikely that the kidney lesion is attributable to drug therapy. Another possibility is that the changes in the renal medullae might be the result of toxaemia or peripheral circulatory failure, which all our cases suffered during life, or to a combination of these two factors. Toxic changes, however, usually affect the proximal renal tubules rather than the distal ones and the focal ischaemic necroses of "shock" have been shown by the microdissection studies of Oliver, MacDowell, and Tracy (1951) and others to be distributed to all parts of the nephrons. Moreover, we have carried out a review of the routine histological sections of the kidneys from 75 recent necropsies performed in our hospital, and it is noteworthy that, although these kidneys included many from patients who had suffered severe degrees of toxaemia or shock or both, only one case was found in which the 
medullary lesions were identical with those seen in the influenzal material. The certified cause of death in this case was lobar pneumonia and hepatic cirrhosis, but reassessment of the clinical, bacteriological, and post-mortem findings and of the available histological material strongly suggested that the patient had, in fact, died of fulminating influenzal pneumonia.

Thus the pathogenesis of the renal lesion remains obscure and its specificity and significance are largely undetermined. Before speculating further it is important to know the findings of other observers who have carried out necropsies on cases of influenza from the recent pandemic.

\section{Summary}

Renal changes in seven fatal cases of influenzal pneumonia, due to virus A (Asian strain), are reported. The morbid anatomy and histology of the renal lesions, which were principally localized to the medullae of the organs, are described and illustrated.

The literature on renal pathology in influenza is briefly reviewed; in several previous reports only cortical changes are described. It has not been possible to form a decided opinion as to the aetiology of the medullary lesions.
We thank the several clinicians at the Royal Free Hospital for allowing us to use their case notes, colleagues in the Department of Pathology for technical assistance, Mr. R. R. Phillips for the photomicrography, and the Routine Diagnostic Laboratory, Colindale, for virological studies.

\section{REFERENCES}

Blanton, W. B., and Irons, E. E. (1918). J. Amer. med. Ass., 71, 1988.

Brit. med. J. (1958), 1, 908 . A Combined Study Group.

Darke, C. S., Watkins, P. H., and Whitehead, J. E. M. (1957). Brit. med. J., 2, 606.

Dever, F. J., Boles, R. S., and Case, E. A. (1919). J. Amer. med. Ass., 72, 265.

Fischer, C. (1957). Münch. med. Wschr., 99, 187.

Giles, C., and Shuttleworth, E. M. (1957). Lancet, 2, 1224.

Herrmann, R. E., Ogura, G. I., Johnson, E. S., Toll, H. W., and White, W. C. (1958). J. Amer. med. Ass., 166, 467.

Lucke, B., Wight, T., and Kime, E. (1919). Arch. intern. Med., 24, 154.

Mogabgab, W. J., Green, I. J., and Dierkhising, O. C. (1954). Science, 120,320 .

and Phillips, I. A. (1955). Proc. Soc. exp. Biol. (N.Y.), 89, 654.

Neilson, D. B. (1958). Brit. med. J., 1, 420.

Nuzum, J. W., Pilot, I., Stangl, F. H., and Bonar, B. E. (1918). $J$. Amer. med. Ass., 71, 1562.

Oliver, J., MacDowell, M., and Tracy, A. (1951). J. clin. Invest., 30, 1305.

Opie, E. L. (1928). Arch. Path. (Chicago), 5, 285.

Plenge, K. (1952). Dtsch. med. J., 3, 571.

Roberts, G. B. S. (1957). Lancet, 2, 944.

Symmers, D. (1918). J. Amer. med. Ass., 71, 1482.

Symonds, C. P. (1918). Lancet, 2, 664.

Winternitz, M. C., Wason, I. M., and McNamara, F. P. (1920). The Pathology of Influenza, p. 38. Yale Univ. Press, New Haven. 